\title{
ANALISIS SEMIOTIK MASALAH ETIKA DALAM IKLAN (Studi Kasus Iklan Majalah “Ayahbunda” Tahun 2013 dan Tahun 2014)
}

\author{
Lucy Max \\ kakaramemax@gmail.com \\ Dosen Prodi Ilmu Komunikasi Universitas Katolik Widya Mandira
}

\begin{tabular}{|c|c|}
\hline Article Info & Abstract \\
\hline $\begin{array}{l}\text { Keyword: } \\
\text { ethics, advertisement, rationality, } \\
\text { creativity }\end{array}$ & $\begin{array}{l}\text { Advertising is needed for anticipating a crisis in a company or institution in order to } \\
\text { gain a positive image from society. However, this research saw that there is a } \\
\text { problematic issue of ethics in the advertising itself. By doing semiotic analysis on the } \\
\text { advertisement of AC Sharp and the Dettol Liquid Soap published by "Ayahbunda" } \\
\text { Magazine this research finds that there is a potential problem of ethics in those } \\
\text { advertisements that can be explained by these four issues; firstly, the message of the } \\
\text { advertisement have bias regarding its truthfulness and rationality; secondly } \\
\text { regarding the recognizing ethics issues, the advertisement was trapped between } \\
\text { rationality and creativity; thirdly, the advertisement has neglected principle of } \\
\text { humaneness and finally there is a miss-interpretation and false image on both } \\
\text { advertisement. }\end{array}$ \\
\hline & Copyright (C) 2018 Interaksi: Jurnal Ilmu Komunikasi. \\
\hline
\end{tabular}

\section{PENDAHULUAN}

Sebagai salah satu fungsi manajemen, bidang public relations memegang peranan penting terutama untuk menciptakan hubungan komunikasi yang harmonis dan saling menguntungkan antara organisasi dengan stakeholdersnya. Dalam prakteknya, bidang PR melayani kepentingan publik internal dan publik eksternal. Ini tentu bukanlah hal yang mudah, karena setiap kategori publik memiliki karakteristik yang berbeda dan pada akhirnya membutuhkan pengelolaan komunikasi yang berbeda pula.

Dalam praktek PR kontemporer, salah satu aktifitas PR yaitu advertising. Cutlip, Centre dan Broom (2009: 14) mendefinisikan advertising sebagai “informasi yang ditempatkan di media oleh sponsor tertentu yang jelas identitasnya yang membayar untuk ruang dan waktu penempatan informasi tersebut". Dari definisi tersebut, nampak ada perluasan publik yang terlayani oleh perusahaan melalui iklan-iklan yang digunakan oleh praktisi PR. PR biasanya menggunakan advertising untuk menjangkau publik yang lebih luas, bukan untuk konsumen yang menjadi sasaran marketing.

Pada dasarnya, ada beberapa hal yang melatarbelakangi alasan mengapa perusahaan menggunakan advertising untuk tujuan PR. Advertising diperlukan terutama ketika perusahaan berada dalam situasi kritis atau ketika perusahaan menganggap sudut pandang mereka tidak dimuat secara fair dan seimbang. Advertising juga dibutuhkan ketika perusahaan merasa bahwa publik tidak memahami issue secara benar, dan berbagai situasi lainnya yang berkorelasi dengan pencitraan perusahaan.

Persoalan mulai muncul ketika materi atau isi iklan yang dadigunakan sebagai pilihan tools PR, ternyata memiliki konsekuensi etis, baik yang berasal dari pilihan gambar maupun kata-kata. Konsekuensi etis yang dimaksud terutama lam hal komunikasi antar 
manusia dan bukan dalam artian umum. Richard Johannesen (dalam Jaksa dan Pritchard, 1994:6) mengidentifikasi beberapa area komunikasi yang memiliki konsekuensi pertimbangan etika, yaitu komunikasi interpersonal, diskusi kelompok kecil, komunikasi organisasi, komunikasi politik, periklanan dan media baru. Mengapa penting untuk menelusuri lebih dalam tentang konsekuensi etis pilihan gambar dan kata-kata yang terdapat dalam bahasa iklan? Mickey (2003: 1) secara detail mengemukakan bahwa praktisi PR juga perlu mendekonstruksi pilihan tools PR, sebagai cara untuk menjaga agar apapun program kerja dan moda komunikasi PR dalam prakteknya tidak menimbulkan pandangan-pandangan sinis, tentang kesungguhan praktisi PR untuk menjalankan profesi kehumasannya. Berangkat dengan dasar pemikiran bahwa PR merupakan bagian penting dari budaya kontemporer, maka upaya mendekonstruksi pilihan moda komunikasi PR tersebut merupakan cara untuk menemukan ide dan makna yang ada dibalik tampilan permukaan dari berbagai material komunikasi hasil produksi PR.

Penelitian ini secara khususmenganalisis pilihan kata dan gambar yang terdapat dalam iklan majalah "ayahbunda", yaitu iklan AC Sharp ("ayahbunda" nomor 26 Edisi 24 Desember 2012 - 6 Januari 2013, halaman 3), dan iklan sabun cair Dettol (“ayahbunda" nomor 20 Edisi 06 - 19 Oktober 2014, halaman 45). Iklan-iklan tersebut dipilih terutama karena sebagai iklan dari produk untuk kebutuhan balita dan untuk kebutuhan rumahtangga dengan menggunakan balita dan orang tua balita sebagai model, nampaknya kedua iklan tersebut cenderung menampilkan fakta kekerasan dalam pilihan kata dan gambar.Fenomena tersebut tentu memprihatinkan, terutama karena dewasa ini ada banyak pihak yang peduli dan berjuang untuk meminimalisir potensi penggunaan cara-cara kekerasan, baik verbal, fisik maupun non-verbal, yang ditujukan kepada anak-anak dan kaum perempuan.Beberapa pertanyaan yang menjadi panduan, yaitu bagaimana penggunaan simbolsimbol verbal, baik kata-kata maupun gambar, yang cenderung mengandung unsur kekerasan dalam kedua iklan tersebut? Bagaimana hal tersebut berpotensi menimbulkan masalah etika dalam komunikasi?
Mengapa tetap penting untuk menjadikan etika komunikasi sebagai standar dalam beriklan? Dalam penelitian ini, realitas tentang penggunaan simbolsimbol verbal, baik kata-kata maupun gambar, merupakan hasil konstruksi para pembuat iklan. Kehadiran iklan-iklan tersebut sejak awal dikonstruksikan sebagai bagian dari upaya untuk mendekatkan berbagai produk yang diiklankan tersebut dengan kebutuhan masyarakat umum. Artinya, ada ruang yang terbuka luas bagi masyarakat untuk terlibat secara aktif dalam menanggapi dan atau memaknai iklan-iklan tersebut. Realitas keterlibatan masyarakat umum juga bersifat relatif, karena merupakan hasil konstruksi, yang didalamnya melibatkan berbagai unsur, seperti pengetahuan masyarakat tentang komunikator (pengiklan dan perusahaan yang memproduksi produk tersebut), pun sebaliknya, pengetahuan komunikator (pengiklan dan perusahaan yang memproduksi produk tersebut) tentang siapa masyarakat yang akan diterpa pesan atau yang akan membaca iklan tersebut, serta kemampuan dari masingmasing individu anggota masyarakat untuk menggunakan filter konseptual dalam menyaring pilihan kata-kata dan gambar dalam berbagai iklan tersebut.

Penelitian ini dilakukan dengan tujuan :

1. Untuk menganalisis penggunaan kekerasan visual dan verbal yang terdapat dalam iklan majalah "ayahbunda". Kekerasan visual dan verbal dalam iklan yang dimaksud ditelusuri melalui penggunaan tanda-tanda dan sistem tanda yang terdapat dalam iklan dimaksud.

2. Untuk menguraikan bagaimana potensi masalah etika dalam komunikasi melalui media iklan.

3. Untuk menunjukkan arti penting pengutamaan etika dalam iklan.

\section{Kekuatan Kata dan Makna}

Kekuatan kata-kata telah lama menjadi objek studi komunikasi terutama dalam hal kemampuannya untuk mempengaruhi individu. Pada dasarnya, makna kata ada pada orang atau individu yang menggunakan kata tersebut dan bukan pada kata itu sendiri. Selama tidak ada orang yang menginterpretasi dan menciptakan 
makna atas kata-kata, maka kata -kata tersebut tetaplah hanyalah kata-kata tanpa makna. Hal itu merupakan proses yang sangat dialekstis, yang didalamnya melibatkan proses menciptakan makna atas simbolsimbol yang digunakan untuk mewakili kata tertentu, dalam konteks yang spesifik dan interpretif, dalam bingkai budaya. Bingkai budaya itulah yang nantinya akan mempengaruhi proses pemaknaan denotatif dan konotatif dari kata-kata.Beebe, Beebe dan Redmon (2005:161-164) merekomendasikan tiga gagasan tentang kekuatan kata-kata, yaitu :

1. Words have power to create. Words give us a tool to create the world by naming and labeling what our experience. (...) we are using language to create our own vision of how our experience the world.

2. Words have power to affect thoughts and actions

3. Words have power to affect and reflect culture The words we use to describe our view of the world reflect and further shape our perspective. In turn, help to shape our culture's collective world through our use of language.

Bagi Beebe, Beebe dan Redmon, kata - kata sebenarnya memiliki kekuatan untuk menciptakan (sesuatu, pen), karena pada dasarnya kata - kata menjadi sarana untuk menciptakan dunia, melalui pemberian nama dan labeling, tentang apa yang menjadi pengalaman kita. Dalam kondisi itu, kita akan menggunakan bahasa untuk menciptakan pandangan (pemahaman)sendiri mengenaipengalaman tentang dunia. Kekuatan kata - kata itu juga, masih menurut Beebe, Beebe dan Redmon, mampu merefleksikan berbagai pemikiran dan tindakan kita tentang pengalaman akan dunia yang dialami. Kekuatan kata kata juga mampu mempengaruhi sekaligus merefleksikan budaya. Kata - kata yang kita gunakan, pada tingkat selanjutnya, tidak saja merefleksikan budaya, tetapi sekaligus juga membentuk perspektif atau cara pandang kita tentang pengalaman akan dunia. Melalui penggunaan bahasalah, pengalaman akan dunia tersebut pada akhirnya menciptakan budaya kolektif.

\section{Potensi Masalah Etika dalam Berkomunikasi}

Dalam penelitian ini, pemahaman tentang etika mengacu pada apa yang dikemukakan oleh Jaksa dan Pritchard (1994: 3), yaitu bahwa :

Ethics is concerned with how we should live our lives. It focused on questions about what is right or wrong, fair or unfair, caring on uncaring, good or bad, responsible or irresponsible, and the like. It is concerned with both character and conduct. Thus, it addresses questions about virtues and vices, as well as questions about basic principles and rules we might use to guide and evaluate our conduct.

Artinya, dalam pandangan Jaksa dan Pritchard, etika berkaitan dengan bagaimana kita seharusnya menjalani hidup ("menghidupi hidup"). Di dalamnya, ada beberapa hal yang bisa dipertanyakan, misalnya persoalan seputar apa yang benar dan apa yang salah, adil dan tidak adil, peduli atau tidak peduli, baik atau buruk, bertanggung jawab atau tidak bertanggung jawab, dan sebagainya. Semuanya itu berpusat pada karakter maupun perilaku. Atau dengan kata lain, pertanyaan - pertanyaan tentang etika akan berpusat tentang kebaikan dan keburukan, atau pada berbagai prinsip dasar dan aturan yang kita gunakan untuk memandu sekaligus untuk mengevaluasi perilaku kita.

Dalam komunikasi antar manusia dibutuhkan etika, sebagai aturan moral yang memandu manusia dalam berkomunikasi. Pertanyaan yang muncul kemudian yaitu bagaimana mengidentifikasi potensi persoalan etika dalam komunikasi? Berkaitan dengan hal tersebut, Richard Johannesen ( Pritchard, 1994: 6-7) mengatakan bahwa

Potential ethical issues are inherent in any instance of communication betwen humans to the degree that the communication can be judged on a right-wrong dimension, involves possible significant influence on other humans, and to the degree that the communicator consciously chooses specific ends sought and communicative means to achieve those ends.

Artinya, potensi masalah etika melekat dalam berbagai model komunikasi antar manusia, mulai dari derajat dimana komunikasi dapat dinilai dari dimensi benar salah, termasuk kemungkinan pengaruh terhadap manusia lainnya, sampai pada tingkatan dimana komunikator secara sadar memilih tujuan - tujuan yang spesifik dan mencari cara - cara yang komunikatif untuk mencapai tujuan - tujuan tersebut.

\section{Tujuan Etika dalam Komunikasi}

Arti penting pertimbangan etika dalam berkomunikasi, termasuk komunikasi melalui media massa, idealnya 
disandingkan dengan tujuan mempelajari dan kemudian menerapkan etika dalam berbagai konteks komunikasi. Berkaitan dengan hal tersebut, dengan mengadaptasi pemikiran Jaksa dan Pritchard (1994: 12-18), terdapat lima tujuan etika dalam komunikasi, yaitu Stimulating the moral imagination, Recognizing ethical issues, Eliciting a sense of obligation, Developing analytical skills, dan Tolerating disagreement.

Bagaimana memahami ke-lima tujuan etika tersebut? Pertama, etika bertujuan untuk merangsang imajinasi moral. Item ini berhubungan dengan pembelajaran tentang apa dampak yang mungkin ditimbulkan dari perilaku kita terhadap orang lain, ketika perilaku kita melibatkan pilihan-pilihan sadar tentang cara dan tujuan yang dapat dinilai dengan standar benar-salah. Dalam berbagai bentuk komunikasi antar manusia, melibatkan banyak kemungkinan persinggungan persoalan, baik dari sisi cara memproduksi pesan, moda komunikasi yang dipilih, sampai pada persoalan isi pesan dan terutama kemampuan penerima pesan untuk menganggapi isi pesan tersebut. Dalam konteks pilihan media dan isi pesan yang disebarkan melalui media (termasuk melalui iklan), etika hadir terutama untuk membantu para partisipan untuk sejak awal mempertimbangkan dampak dan atau konsekuensi moral dari proses komunikasi tersebut.

Kedua, tujuan etika untuk membantu mengenali persoalan etika. Kita tidak selalu dapat mengenali dimensi moral dalam setiap situasi. Dibutuhkan pengenalan kritis atas situasi yang dihadapi serta melibatkan penilaian tentang tanggapan seketika, mengidentifikasi asumsi-asumsi yang tidak stabil serta mempertanyakan apakah "tanggapan" secara berdiri sendiri dapat dijadikan sebagai dasar penilaian moral, dan sebagainya.

Ketiga, etika bertujuan untuk menyadarkan orang tentang kewajiban. Dengan item ini, Jaksa dan Pritchard ingin mengingatkan tentang value bahwa penerapan etika dalam praktek jauh lebih penting daripada sekedar penyederhanaannya sebagai persoalan intelektual semata. Item ini terkait dengan apa yang oleh Jaksa dan Pritchard (1994: 15) diidentifikasi sebagai situasi yang membutuhkan refleksi moral dalam pengambilan keputusan. Artinya, para partisipan komunikasi idealnya tidak hanya berfokus pada tujuan untuk menyebarluaskan isi pesan (dengan apapun tujuan yang melatarbelakangi isi pesan tersebut). Setiap individu, sebagai partisipan dalam komunikasi, memiliki kewajiban mendasar untuk mempertimbangkan secara menyeluruh apa dampak yang ditimbulkan secara moral dari keterlibatannya dalam proses komunikasi tersebut.

Keempat, mempertimbangkan etika sebagai cara untuk mengembangkan kemampuan menganalisis.Mempelajari etika akan menjadikan individu mampu berpikir kritis tentang konsep-konsep dasar pertimbangan nilai etika. Misalnya, keadilan, fungsi dan manfaat, tanggungjawab, hak, tugas, penghargaan terhadap diri sendiri dan orang lain, martabat, otonomi, dan sebagainya,sehingga konsepkonsep dasar pertimbangan nilai etika tersebut dapat diterapkan secara konsisten dan koheren. Sekali lagi hal tersebut mengindikasikan bahwatujuan komunikasi tidak dengan serta-merta tercapai ketika pesan disebarluaskan. Para partisipan perlu dengan secara bijak mengembangkan kemampuan untuk menganalisis apa konsekuensi lanjutan yang turut menyertai proses komunikasi tersebut.

Kelima, etika bertujuan untuk membantu orang menghargai atau mentolelir perbedaan pendapat. Masalah moral sangat mungkin menimbulkan prokontra bahkan menimbulkan keraguan dan ketidakpastian. Walaupun sulit mendapatkan kepastian moral, namun alasan yang melatar-belakangi suatu pilihan moral dapat dibuat secara tepat, jika ada toleransi terhadap pilihan yang berbeda yang memiliki alasan moral yang dapat dipertanggung-jawabkan. Item ini sebenarnya berhubungan dengan penjelasan tentang pentingnya mengembangkan kemampuan menganalisis persoalan etika, karena hanya dengan cara itulah para partisipan dapat memahami dan menerima fakta bahwa ada kemungkinan penerimaan yang berbeda dengan tujuan awal komunikasi yang dilakukan. Pada saat itulah, etika membantu orang untuk memahami perbedaan pendapat itu secara objektif, artinya tidak memihak atau memenangkan kepentingan pihak tertentu saja (kepentingan ekonomi, misalnya). Berpikir objektif ini juga dapat diartikan sebagai "cara berpikir yang tidak berprasangka atau tidak bertolak dari 
anggapan - anggapan yang tidak bisa dipertanggungjawabkan secara rasional" (Bertens, 2007: 303). Jika cara berpikir objektif itu yang kita gunakan ketika berhadapan dengan pendapat yang berbeda, maka pertimbangan dan keputusan moral kita juga dapat dipertanggungjawabkan secara rasional.

\section{Kekerasan Melalui Media}

Kekhawatiran tentang maraknya kekerasan melalui media, bukan hal yang tidak mendasar. Setiap informasi, apapun bentuknya, yang didistribusikan melalui media memiliki potensi besar mengandung unsur kekerasan. Seperti yang diungkapkan oleh Haryatmoko (2007: 119), yaitu bahwa "pornografi, kekerasan naratif, agresivitas, kekerasan virtual, kekerasan simbolik dan kekerasan lembut yang manipulatif merajalela tanpa ada struktur kuat yang melawannya".Kekerasan dapat diartikan sebagai "prinsip tindakan yang mendasarkan diri pada kekuatan untuk memaksa pihak lain tanpa persetujuan" (Lardellier, dalam Haryatmoko, 2007: 119). Hal mendasar yang umumnya terkandung dalam kekerasan, yaitu adanya dominasi satu pihak terhadap pihak lain. Dominasi tersebut dapat dilakukan dalam berbagai bentuk, misalnya fisik, moral, psikologis atau melalui gambar (Haryatmoko, 2007: 120). Artinya, kekerasan tidak harus hanya dalam bentuk fisik, tetapi bisa juga menyerang dan melumpuhkan psikologis seseorang, termasuk cara berpikir dan afeksinya.Haryatmoko (2007: 121) secara detail melukiskan bagaimana kekerasan melalui gambar yang ditampilkan atau yang ditayangkan melalui media massa, sesungguhnya harus diwaspadai sebagai ancaman terhadap penerapan etika. Menurutnya,

Gambar membuat kekerasan menjadi biasa karena menghadirkan yang umum dan normal dalam dunia tontonan yang diatur sedemikian rupa sehingga pemirsa dibiasakan tidak bisa melakukan apa-apa. Padahal penggambaran di media telah menciptakan dunia yang sulit dibedakan antara riil, simulasi, hiperriil dan bohong.

\section{Semiotika Roland Barthes}

Kajian iklan dalam perspektif semiotika ditelusuri melalui identifikasi sistem tanda. Sistem tanda yang terdapat dalam iklan berupa lambang verbal dan ikon. Tentang hakekat penggunaan lambang dalam iklan, menurut Sobur (2003: 116), lambang dalam iklan terdiri atas dua jenis, yaitu lambang verbal dan lambang nonverbal. Lambang verbal ditelusuri melalui penggunaan bahasa, sedangkan lambang nonverbal dikenali melalui bentuk dan warna yang disajikan dalam iklan, yang tidak secara khusus meniru realitas. Sedangkan ikon merupakan bentuk dan warna yang serupa atau mirip dengan keadaan sebenarnya, seperti gambar benda, orang atau hewan. Artinya, ikon tetap diperlakukan sebagai lambang. Di lain sisi, kajian sistem tanda dalam iklan juga dapat dilakukan melalui apa yang menjadi objek dari iklan tersebut. Menurut Sobur (2003: 116), yang terutama harus diperhatikan dalam menganalisis sistem tanda dalam iklan yaitu penafsiran kelompok sasaran dalam proses interpretan.

Untuk menganalisis iklan, digunakan model analisis semiotik Roland Barthes, yang meliputi pesan linguistik, pesan ikonik yang terkodekan, serta pesan ikonik yang tak terkodekan (Sobur, 2003: 119). Pertama, tentang pesan linguistik. Item ini meliputi semua kata dan kalimat dalam iklan. Inti pesan linguistik terkandung dalam nuansa khas yang muncul dari objek yang diiklankan tersebut. Di sini dianalisis makna denotasi dan konotasi dari objek iklan tersebut. Makna denotasi dapat diartikan sebagai "makna kata atau kelompok kata yang didasarkan atas penunjukan yang lugas pada sesuatu diluar bahasa atau yang didasarkan atas konvensi tertentu dan bersifat objektif" (KKBI Daring:https://kbbi.kemdikbud.go.id/ diakses Sabtu 26 Mei 2018, pukul 15.17 Wita).Sedangkan makna konotasi dapat dipahami sebagai "tautan pikiran yang menimbulkan nilai rasa pada seseorang ketika berhadapan dengan sebuah kata; makna yang ditambahkan pada makna denotasi (KKBI Daring:https://kbbi.kemdikbud.go.id/diakses Sabtu 26 Mei 2018, pukul 15.17 Wita).

Kedua, pesan ikonik yang terkodekan. Seturut Roland Barthes, item ini merupakan konotasi visual yang diturunkan dari penataan elemen-elemen visual dalam iklan. Untuk memahami hal ini, perlu dipahami bagaimana struktur semiosis menjelaskan hubungan antara kenyataan dengan jenis dasarnya, dalam hal ini tentang icon. Icon didefinisikan sebagai "sesuatu yang melaksanakan fungsi sebagai penanda yang serupa dengan bentuk obyeknya (terlihat pada gambar atau lukisan" (Sobur, 2002: 98).Kata icon juga 
dipakai oleh Pierce untuk menggambarkan jenis tanda yang penandanya memiliki hubungan kemiripan dengan obyek yang diacunya (Baryadi, 2007:1).Dalam konteks analisis iklan, pesan ikonik yang terkodekan ini ditelusuri melalui penggambaran kreatif yang ada dalam iklan tersebut untuk menunjukkan produk dan fungsi produk yang diiklankan. Misalnya, apa hubungan antara elemen gambar dan elemen tertulis, tanda dan lambang apa saja yang ada serta peran apa yang dimainkan oleh tanda dan lambang tersebut? Bagaimana background iklan tersebut? Kegiatan apa yang terjadi atau yang digambarkan dalam iklan tersebut dan apa artinya?

\section{Ketiga, pesan ikonik yang tak} terkodekan. Item ini digunakan untuk menunjukkan makna denotasi harfiah yaitu pemahaman langsung dari gambar dan pesan dalam iklan, tanpa mempertimbangkan kode sosial yang lebih luas (Sobur, 2003: 119). Artinya, dalam tahap ini, dilakukan penelusuran dari sudut pandang pembuat iklan, yang meliputi, misalnya bagaimana desain iklan digunakan untuk menggambarkan produk dan keunggulannya? Bagaimana mengenai bahasa yang digunakan dalam iklan? Apakah terutama memberikan informasi ataumenimbulkan semacam responsi emosional atau keduanya? (diadaptasi dari Sobur, 2003: 117 - 118).

\section{METODA PENELITIAN}

Penelitian ini merupakan penelitian deskriptif yang bersifat interpretatif, yang menginterpretasi dan menerjemahkan makna dibalik penggunaan tanda, sistem tanda dan budaya dalam iklan majalah “ayahbunda",yang menjadikan perempuan dan anak anak sebagai model iklan.Dengan menggunakandesain penelitian analisis semiotik,data dalam penelitian ini, yaitu tentang eksekusi kreatif iklan, ditelusuri untuk mendapatkan gambaran yang menyeluruh tentang makna dibalik pilihan gambar dan kata dalam iklan tersebut. Subyek penelitian ini, yaitu kata-kata dan gambar yang terdapat dua buah iklan dalam majalah "ayahbunda" yaitu : iklan AC Sharp ("ayahbunda" nomor 26 Edisi 24 Desember 2012 - 6 Januari 2013, halaman 3) dan iklan sabun cair Dettol ("ayahbunda" nomor 20 Edisi 06 - 19 Oktober 2014, halaman 45). Kedua iklan tersebut dipilih terutama karena sebagai iklan dari produk untuk kebutuhan anak-anak dan keluarga dengan menggunakan anak dan atau orang tua sebagai model, cenderung menampilkan fakta kekerasan yang kontras dalam pilihan kata dan gambar.
Diksi dalam kedua iklan tersebut cenderung mengandung kekerasan verbal, sedangkan pilihan gambar lebih menonjolkan mood keluarga yang bahagia dan dunia bermain anak - anak yang penuh dengan kegembiraan dan keceriaan. Jenis data dalam penelitian ini yaitu data primer yaitu kata-kata dan gambar dalam iklan AC Sharp ("ayahbunda" nomor 26 Edisi 24 Desember 2012 - 6 Januari 2013, halaman 3) dan iklan sabun cair Dettol ("ayahbunda" nomor 20 Edisi 06 - 19 Oktober 2014, halaman 45). Sedangkan data sekunder meliputi literatur serta bahan pendukung dari internet yang relevan dengan kajian tentang etika iklan. Data dalam penelitian ini didapatkan dengan cara mendokumentasi (membuat kliping) iklan AC Sharp ("ayahbunda" nomor 26 Edisi 24 Desember 2012 - 6 Januari 2013, halaman 3) dan iklan sabun cair Dettol ("ayahbunda" nomor 20 Edisi 06 - 19 Oktober 2014, halaman 45).Data dalam penelitian ini dianalisa dengan menggunakan skema analisis semiotik Roland Barthes, dengan tiga panduan utama yaitu pesan linguistik, pesan ikonik yang terkodekan, dan pesan ikonik yang tak terkodekan. Sedangkan untuk interpretasi data, digunakan skema tujuan etika dalam komunikasi menurut Jaksa dan Pritchard yang dielaborasikan dengan pemikiran Gordon, Kittross dan Reuss.Dengan menggunakan patokan kriteria validitas dalam ranah penelitian kualitatif (Denzin dan Lincoln, 2009: 641), termasuk penelitian semiotik, beberapa standar validitas yang digunakan dalam penelitian ini, yaitu, pertama, validitas sebagai kebudayaan. Hasil penelitian ini merupakan refleksi, penerapan dan produksi dari sudut pandang peneliti, yangditerapkan untuk menginterpretasi temuan data penelitian. Hal itu dianggap sebagai hal yang benar dalam upaya untuk menyertakan lebih banyak sudut pandang, sebagai cara bagi peneliti untuk mempertanggungjawabkan tujuan dan tema penelitian ini. Kedua,validitas sebagai relevansi advokasi. Aspek ini menekankan kemanfaatan dan pemberdayaan penelitian agar bermanfaat dan mengangkat martabat kelompok masyarakat yang menjadi sasaran iklan majalah.

Analisis semiotik Barthes dioperasionalkan dengan cara :

1. Pesan linguistik

Meliputi semua kata dan kalimat dalam iklan majalah "ayahbunda", yaitu iklan AC Sharp 
(“ayahbunda" nomor 26 Edisi 24 Desember 2012 6 Januari 2013, halaman 3) dan iklan sabun cair Dettol ("ayahbunda" nomor 20 Edisi $06-19$ Oktober 2014, halaman 45).

2. Pesan ikonik yang terkodekan

Item ini akan ditelusuri melalui makna konotasi visual yang yang terdapat dalam bentuk gambar yang ada dalam iklan AC Sharp ("ayahbunda" nomor 26 Edisi 24 Desember 2012 - 6 Januari 2013, halaman 3) dan iklan sabun cair Dettol ("ayahbunda" nomor 20 Edisi 06 - 19 Oktober 2014, halaman 45).

3. Pesan ikonik yang tak terkodekan

Digunakan untuk menunjukkan makna denotasi harafiah yaitu pemahaman langsung darigambar dan kata-kata verbal yang digunakan dalam iklan AC Sharp ("ayahbunda" nomor 26 Edisi 24 Desember 2012 - 6 Januari 2013, halaman 3), dan iklan sabun cair Dettol(“ayahbunda" nomor 20 Edisi 06 - 19 Oktober 2014, halaman 45),tanpa mempertimbangkan makna pertimbangan sosial dan budaya secara lebih luas.

\section{HASIL}

Dengan menggunakan model analisis semiotik Roland Barthes, didapatkan hasil sebagai berikut:

1. Iklan majalah "ayahbunda", yaitu iklan AC Sharp (“ayahbunda" nomor 26 Edisi 24 Desember 2012 6 Januari 2013, halaman 3)

a. Pesan Linguistik. Dalam iklan tersebut tercantum kata-kata dan kalimat berikut ini:

SHARP

POLISINYA POLUSI.

MENJAGA UDARA, MELINDUNGI KELUARGA

Lindungi keluarga anda dari ancaman musuh yang tak terlihat dengan Sharp Plasmacluster Air Purifier. Dilengkapi sensor monitor untuk mendeteksi tingkat kebersihan udara di dalam ruangan. Kini dengan Ion Plasmacluster HD 7000 semakin efektif melumpuhkan bakteri, jamur dan virus berbahaya. Lawan polusi dengan Sharp Plasmacluster Air Purifier. Polisinya polusi.

Makna denotasi dari kata-kata dan kalimat dalam iklan tersebut mengacu pada fungsi AC Sharp Plasmacluster Air Purifier untuk melindungi keluarga dari ancaman berbahaya yang datang dari musuh yang tak terlihat yang akan selalu ada di dalam setiap rumah tempat tinggal (fisik) yaitu bakteri, jamur dan virus berbahaya. Untuk menonjolkan fungsi produk tersebut, ada beberapa pilihan kata yang dapat ditelusuri relevansinya dengan fungsi produk tersebut, yaitu, pertama, kata "polisi”. Berdasarkan KBBI, kata "polisi' dimaknai secara denotasi sebagai "badan pemerintah yang bertugas memelihara keamanan dan ketertiban umum (menangkap orang yang yang melanggar undang - undang dan sebagainya)" atau "anggota badan pemerintah (pegawai negara yang bertugas menjaga keamanan dan sebagainya)" (KKBI Daring:https:// kbbi.kemdikbud.go.id/diakses Sabtu 26 Mei 2018, pukul 15.36 WITA). Kedua, kata “ancaman” yang dalam KBBI diartikan sebagai "menyatakan maksud (niat, rencana) untuk melakukan sesuatu yang merugikan, menyulitkan, menyusahkan atau mencelakakan pihak lain” (KKBI Daring:https:// kbbi.kemdikbud.go.id/diakses Sabtu 26 Mei 2018, pukul 15.40 WITA). kata tersebut juga memiliki arti "memberi pertanda atau peringatan mengenai kemungkinan malapetaka yang bakal terjadi” ((KKBI Daring:https://kbbi.kemdikbud.go.id/diakses Sabtu 26 Mei 2018, pukul 15.43 WITA). Ketiga, kata “musuh”. Kata ini memiliki beberapa arti, yaitu "lawan (berkelahi, bertengkar, berperang, bertanding, berjudi, dan sebagainya) ; seteru”. Selain itu, kata “musuh” juga diartikan sebagai "bandingan, imbangan, tandingan" atau "sesuatu yang mengancam (kesehatan, keselamatan); yang merusakkan (KKBI Daring:https://kbbi.kemdikbud.go.id/diakses Sabtu 26 Mei 2018, pukul 15.50 WITA). Keempat, kata "melumpuhkan" yang memiliki arti "menyebabkan lumpuh (tidak bertenaga lagi, tidak dapat berjalan atau berfungsi lagi, dan sebagainya) (KKBI Daring:https://kbbi.kemdikbud.go.id/diakses Sabtu 26 Mei 2018, pukul 15.52 WITA).

Sedangkan makna konotasinya berhubungan dengan kalimat yang menyertai kata - kata "polisi", "ancaman", “musuh" dan kata "melumpuhkan". Kalimat - kalimat tersebut, yaitu "polisinya polusi", "lindungi keluarga anda dari ancaman musuh yang tak terlihat dengan Sharp Plasmacluster Air Purifier", "kini dengan Ion Plasmacluster HD 7000 semakin efektif melumpuhkan bakteri, jamur dan virus berbahaya".

\section{b. Pesan ikonik yang terkodekan}

Item ini ditelusuri melalui bagaimana penataan elemen - elemen visual (gambar dan kata) dalam iklan tersebut mampu menghubungkan antara kenyataan dan fungsi produk yang ditawarkan Dalam pandangan Barthes (Sobur, 2002: 98), penataan elemen visual dalam struktur semiosis akan menjelaskan tentang hubungan antara kenyataan dengan icon. Terdapat dua hal yang 
digarisbawahi, yaitu, pertama, fungsi produk. Sharp Plasmacluster Air Purifier merupakan salah satu produk elektronik pembersih udara untuk menghasilkan udara bersih dan sehat yang dilengkapi dengan teknologi Plasmacluster HD 7000 yang aktif sehingga mampu menonaktifkan virus, bakteri, jamur dan bau yang tidak sedap (termasuk bau rokok dan hewan peliharaan) Dalam situs resmi Sharp dijelaskan bahwa "pada dasarnya air purifier (pembersih udara) adalah alat elektronik yang dapat membantu untuk memfilter polusi udara yang terikat bersama udara yang masuk" (https://www.sharp-indonesia.com, diakses Sabtu, 26 Mei 2018, pukul 17.47 WITA). Kedua, penggambaran visual (gambar). Konotasi visual yang terlihat dari penataan elemen-elemen visual dalam iklan tersebut, yaitu: gambar seorang ibu muda yang sedang duduk di kursi sofa empuk dan bersih. Ibu muda tersebut sedang menjaga anak balita laki-lakinya yang sedang bermain di lantai beralaskan karpet tebal. Di atas karpet tebal tersebut berserakan beberapa mainan anak. Fungsi Sharp Plasmacluster Air Purifier divisualisasikan dengan gambar sebuah robot yang sedang melayang-layang di udara (di dalam rumah dimana ibu dan anak tersebut berada) sambil menembak (melalui sebelah tangannya) bakteri, jamur dan virus berbahaya. Bakteri, jamur dan virus berbahaya divisualisasikan dengan gambar dua makhluk berbentuk aneh (secara fisik; visualisasi kreatif) dan cenderung menakutkan bagi anak-anak.

c. Pesan ikonik yang tak terkodekan

Hasil penelitian dalam item ini berhubungan dengan makna denotasi desain iklan tanpa menyandingkannya dengan makna lain selain kaitan langsung antara gambar dan makna (diadapatasi dari Sobur, 2003: 119). Artinya, dalam item ini, perhatian diarahkan pada apa tujuan pengiklan (yang mewakili produsen produk) mengiklankan produk tersebut? Tujuan iklan terutama untuk memperkenalkan produk, baik barang maupun jasa, kepada masyarakat (pangsa pasar) dengan harapan agar produk tersebut dapat diterima (Hendy, 2009: 72).

Bagaimana dengan iklan produk Sharp tersebut? Dengan menggunakan pemikiran dari Hendy (2009: 90-91), dapat dikatakan bahwa gaya eksekusi pesan dalam iklan Sharp Plasmacluster Air Purifier yaitu menggunakan tema aktivitas/rutinitas kehidupan.
Dalam gaya ini, pengiklan menggunakan hal - hal yang lumrah terjadi dalam aktivitas keseharian individu, yaitu ketika seorang ibu menemani anaknya bermain. Efek yang diharapkan yaitu produk tersebut dapat diterima sebagai bagian yang penting (karena dapat memurnikan udara) dalam aktifitas keluarga. Di titik ini, dapat dilihat relevansi antara tema yang diusung dengan pilihan media, yaitu majalah "ayahbunda" yang merupakan majalah keluarga. Dalam situs resminya, dijelaskan bahwa majalah "ayahbunda" ini merupakan bacaan yang komprehensif bagi orang tua muda (kategori majalah ibu dan balita), dengan frekuensi terbit dwi mingguan dan diterbitkan oleh PT Gaya Favorit Press sejak tahun 1976 (http:// www.ayahbunda.co.id, diakses Sabtu 26 Mei 2018, pukul 19.30 WITA). Artinya, perpaduan antara gambar dan kata-kata dalam iklan ini menyodorkan informasi langsung bahwa untuk melindungi anak-anak dari ancaman bahaya bakteri, kuman dan virus ketika mereka bermain, setiap keluarga membutuhkan Sharp Plasmacluster Air Purifier untuk melindungi mereka.

II. Iklan majalah "ayahbunda", yaitu iklan sabun cair Dettol ("ayahbunda" nomor 20 Edisi 06 - 19 Oktober 2014, halaman 45)

a. Pesan Linguistik. Dalam iklan tersebut tercantum kalimat berikut ini :

Apa yang dikhawatirkan oleh ribuan ibu? Dettol baru - baru ini melakukan survey kepada ibu ibu Indonesia dan menanyakan penyakit yang paling membuat mereka khawatir. 4.500 ibu menyebutkan sebanyak 53 penyakit yang mebuat mereka khawatir.Penyakit yang paling dikhawatirkan: diare, influenza, batuk.Penyakit yang paling sering diderita: influenza, batuk, pilek.Mengapa ibu khawatir terhadap banyak penyakit walaupun penyakit tersebut tidak sering diderita? Hal tersebut dikarenakan bahaya yang mengancam, contohnya $25 \%$ dari total kasus diare yang menyebabkan kematian anak berumur $1-4$ tahun. Menurut hasil survey, ibu akan melakukan hal berikut ini ketika si kecil sakit: 1) Memberi obat-obatan sesuai resep dokter ataupun saran dari apotek, 2) Memberi makanan dengan nutrisi yang lebih baik, 3) Membawa ke dokter setelah perawatan di rumah tidak membuahkan hasil.Tetapi ada cara untuk mencegah sebelum si kecil terjangkit penyakit. Untuk melindungi anak, pastikan dia menggunakan produk dengan anti bakteri ketika mencuci tangan dan mandi. Beralihlah ke tingkat perlindungan terdepan,Dettol. Secara alamiah terbukti membunuh 100 jenis kuman penyebab penyakit. Dettol 100\% yakin.Dettol $100 \%$ yakin.MEMBUNUH 100 KUMAN PENYEBAB PENYAKIT 
Makna denotasi dari kata-kata dan kalimat yang terdapat dalam iklan tersebut (terutama pilihan kata untuk menggambarkan kehebatan sabun Dettol) yaitu keyakinan bahwa sabun Dettol memiliki kemampuan untuk membunuh/mematikan/melenyapkan 100 jenis kuman penyebab penyakit yang biasanya diderita anakanak. Beberapa pilihan kata yang dapat ditelusuri makna denotasinya dalam iklan ini, yaitu kata 'khawatir", kata "bahaya", kata "mengancam", dan kata "membunuh". Kata "khawatir" dalam KBBI diartikan sebagai "takut (gelisah, cemas) terhadap suatu hal yang belum diketahui dengan pasti". Kata "bahaya" memiliki arti "yang (mungkin) mendatangkan kecelakaan (bencana, kesengsaraan, kerugian, dan sebagainya)”. Untuk kata "mengancam", selain memiliki arti seperti yang telah dijelaskan sebelumnya pada penjelasan tentang pesan linguistik iklan Sharp Plasmacluster Air Purifier, juga memiliki arti "diperkirakan akan menimpa". Sedangkan kata "membunuh" (mematikan/ melenyapkan) memiliki arti "menghilangkan (menghabisi;mencabut) nyawa; mematikan” (KKBI Daring:https://kbbi.kemdikbud.go.id/diakses Sabtu 26 Mei 2018, pukul 19.40 Wita).

Untuk makna konotasi, pesan linguistik dalam iklan ini berhubungan dengan penyodoran gagasan bahwa terdapat 100 jenis kuman berbahaya penyebab penyakit yang terdapat di sekitar lingkungan dan hanya sabun Dettollah yang sanggup mengatasi kuman-kuman berbahaya tersebut. Makna konotasi tersebut muncul seiring dengan kalimat - kalimat yang digunakan dalam iklan tersebut, yaitu "Dettol baru - baru ini melakukan survey kepada ibu - ibu Indonesia dan menanyakan penyakit yang paling membuat mereka khawatir", serta kalimat "Hal tersebut dikarenakan bahaya yang mengancam, contohnya $25 \%$ dari total kasus diare yang menyebabkan kematian anak berumur 1 - 4 tahun". Untuk kata "membunuh" dalam iklan tersebut bahkan muncul sebanyak dua kali, kemunculan yang kedua bahkan ditulis dalam huruf kapital, yaitu "Secara alamiah terbukti membunuh 100 jenis kuman penyebab $\begin{array}{lllll}\text { penyakit. } & \ldots & \text { MEMBUNUH } & 100 & \text { KUMAN }\end{array}$ PENYEBAB PENYAKIT".

b. Pesan ikonik yang terkodekan

Penelusuran item ini melalui fungsi produk, menyodorkan informasi bahwa sabun cair Dettol (antiseptik) dapat digunakan untuk membantu melindungi tubuh dari infeksi pada luka, lecet dan gigitan serangga. Sabun ini juga dapat digunakan untuk pertolongan pertama, medis dan kebersihan pribadi (www.dettol.co.id, diakses Sabtu 26 Mei 2018, pukul 19.45 Wita). Sedangkan dari sisi penggambaran visual, penataan elemen-elemen visual yang terdapat dalam iklan tersebut yaitu: gambar seorang anak laki-laki kecil yang sedang berusaha mengambil bola dengan posisi tertelungkup di tanah, sehingga seluruh tubuhnya terkena lumpur coklat. Lumpur coklat dikonotasikan mengandung 100 jenis kuman berbahaya penyebab penyakit. Pesan yang dikirimkan oleh iklan ini yaitu agar para ibu tidak usah khawatir bila sang anak bermain lumpur, karena ada sabun Dettol yang akan "mengamankan"anak tersebut dari bahaya lumpur bercampur kuman penyakit.

c. Pesan ikonik yang tak terkodekan

Dalam iklan ini digambarkan seorang anak lakilaki kecil yang sedang bermain bola di dalam genangan lumpur. Anak laki-laki tersebut sedang berusaha mengambil bola dengan posisi tertelungkup di tanah, sehingga seluruh tubuhnya terkena lumpur coklat. Sama halnya dengan iklan Sharp Plasmacluster Air Purifier, gaya eksekusi pesan dalam iklan ini juga mengambil tema aktivitas/rutinitas kehidupan. Bermain merupakan bagian dari keseharian anak - anak. Di titik ini, syarat klasifikasi item aktifita/rutinitas kehidupan pun menjadi terpenuhi (Hendy, 2009: 90). Dunia anak - anak yang sebagian besar diisi dengan bermain, rupanya menarik perhatian pembuat iklan, yang mensiasatinya dengan memfokuskan pada apa yang bisa dilakukan para ibu untuk melindungi anak - anak ketika mereka bermain. Dalam dunia bermain anak tersebut, bersentuhan dengan lumpur, ketika mereka bermain bola, sangat mungkin dialami oleh anak - anak dan pada saat itulah mereka beresiko terkena berbagai kuman penyakit. Pemilihan majalah 
"ayahbunda" sebagai tempat untuk beriklan menjadi pilihan yang tepat mengingat orang tua muda merupakan segmen pembaca majalah tersebut.

\section{PEMBAHASAN}

\section{Potensi Masalah Etika Dalam Iklan}

Bagaimana mengenali ada atau tidaknya unsur kekerasan dan atau masalah etika lainnya dalam kedua iklan tersebut? Dengan menggunakan gagasan Beebe, Beebe dan Redmon tentang kekuatan kata-kata (2005: 161-164), maka dapat diuraikan sebagai berikut :

a) Kata-kata memiliki kekuatan untuk menciptakan dunia

Pada dasarnya, manusia akan menciptakan dunianya sendiri melalui penggunaan kata-kata yang dianggap mewakili apa yang menjadi pengalamannya atas dunia tersebut. Semuanya itu dilakukan melalui proses pemberian nama dan label (predikat) terhadap pengalaman akan dunia tersebut. Dalam iklan Sharp nampak bahwa penggunaan gambar-gambar pribadi (ibu dan anak) telah memberi batasan langsung tentang keluarga yang membutuhkan perlindungan (ibu harus memastikan bahwa ketika anaknya bermain, tidak ada bakteri mematikan yang dapat mengganggu kesehatan sang anak). Iklan ini menciptakan "dunia” yang penuh dengan ancaman bakteri jahat dan berbahaya dan yang hanya bisa diatasi dengan AC Sharp.

Sedangkan dalam iklan sabun Dettol, dunia yang diciptakan dalam iklan ini terutama dunia bermain anak -anak yang penuh dengan resiko terkontaminasinya anak-anak dengan berbagai jenis kuman penyebab penyakit. Dunia bermain anak-anak tersebut rupanya telah menjadi ajang kekahawatiran para ibu (bahasa iklan : ribuan ibu) tentang penyakit yang berpotensi menyerang anak-anak karena lingkungan yang tidak steril.

b) Kata-kata memiliki kekuatan untuk mempengaruhi pikiran dan tindakan.

Item ini berhubungan dengan tema, mood dan elemen tertulis yang terkandung dalam iklan. Iklan AC Sharp, misalnya, mengusung tema kejernihan udara untuk alasan kesehatan keluarga. Namun, saat yang bersamaan iklan ini juga mengusung tema tentang keluarga modern dengan standar hidup tertentu, yaitu memiliki Sharp Plasmacluster Air Purifier sebagai standar kualitas keluarga modern. Desain iklan, terutama dalam pemilihan gambar, pada akhirnya menciptakan mood "keluarga sehat, riang, ceria, bersih, tanpa polusi", lagi-lagi karena mereka meggunakan Sharp Plasmacluster Air Purifier. Di lain sisi, pilihan gambar robot dan karakter bakteri memunculkan mood "pengawasan" dari robot terhadap aktifitas keluarga disertai kekerasan (robot yang menembak mati kuman). Sedangkan untuk elemen tertulis, iklan Sharp menguatkan mood yang ditampilkannya melalui diksi “menjaga udara ‘, "melindungi keluarga”, "ancaman”, “musuh", "mendeteksi“, "melumpuhkan”, "berbahaya”, "lawan", dan kata "polisi".

Dalam iklan sabun Dettol, tema yang muncul yaitu keceriaan anak-anak ketika mereka bermain (tema ini muncul melalui gambar) dan kekhawatiran ribuan ibu tentang penyakit yang paling sering menyerang anakanak (tema ini muncul melalui pilihan kata dan informasi tentang hasil survey kesehatan yang ditampilkan dalam iklan tersebut. Sebagai catatan, iklan ini menggunakan 1 halaman penuh). Dengan tema seperti itu, mood yang ditonjolkan dalam iklan Dettol ini yaitu keyakinan bahwa sabun dettol dapat melenyapkan kekhawatiran para ibu. Diksi "100\% yakin membunuh 100 kuman penyebab penyakit" menguatkan mood tersebut. Diksi tersebut sekaligus berfungsi sebagai elemen tertulis untuk menguatkan mood tentang keyakinan yang seharusnya dimiliki oleh para ibu dengan menggunakan sabun Dettol. Iklan ini sebenarnya memberikan informasi tentang perilaku antisipasi para ibu dalam daily activity mereka ketika anak-anak terserang penyakit. Respons emosional tercipta justru ketika iklan ini menggunakan beberapa pilihan kata yang cenderung provokatif, misalnya pilihan kata 'bahaya', “mengancam', dan kata "membunuh" yang digunakan untuk menguatkan penjelasan atas hasil survey kesehatan terhadap para ibu (sebagai bagian integral dari iklan tersebut).

c) Kata-kata memiliki kekuatan untuk mempengaruhi sekaligus merefleksikan budaya.

Item ini berhubungan dengan latar belakang pandangan sosial dan budaya yang dikomunikasikan secara tidak langsung melalui iklan. Pilihan kata "polisinya polusi" dalam iklan Sharp dapat dikaitkan dengan budaya 
militeristik yang dalam kurun waktu yang sangat panjang telah menjadi bagian dalam keseharian hidup masyarakat Indonesia. Mengapa harus menggunakan kata "polisi" dan bukan kata lainnya? Meskipun memang, ada argumentasi lain yang perlu digaris bawahi tentang fungsi polisi. Polisi menjadi sipil setelah secara organisasional tidak lagi berada dalam kesatuan ABRI. Polisi disebut pihak berwajib, penjaga keamanan dan pelayan administratif masyarakat. Secara aksiologis, tugas polisi yaitu melayani masyarakat secara ke dalam, sedangkan tentara membela masyarakat dan negara terhadap serangan dari luar.

Berangkat dengan dasar pemikiran bahwa budaya adalah refleksi dari cara berpikir suatu masyarakat, maka latar belakang keluarga modern yang ditampilkan dalam pilihan model iklan Sharp tersebut merepresentasikan idealisme dalam konteks ekonomi modern dengan indikator pencapaian ekonomi yang matang (dengan memiliki Sharp Plasmacluster Air Purifier. Hanya keluarga dengan latar belakang ekonomi tertentulah yang mampu membeli teknologi pemurni udara tersebut. Teknologi pemurni udara tersebut saat yang bersamaan juga menjadi ikon keluarga modern).Sedangkan dalam iklan sabun Dettol dapat dikaitkan dengan "kegamangan" gender dalam hal pengasuhan anak. Mengapa hanya para ibu yang khawatir tentang kesehatan anak-anak? Apakah hal tersebut tidak berlaku bagi para ayah? Mengapa pengawasan terhadap kebiasaan anak-anak mencuci tangan setelah selesai bermain dan atau sebelum makan menjadi urusan sepenuhnya kaum ibu? Pada tingkat tertentu, apa yang ditampilkan dalam iklan sabun Dettol ini sebenarnya juga merepresentasikan kenyataan yang ada dalam masyarakat. Kaum ibu masih menjadi pihak pertama dan terutama yang bertanggung jawab atas masalah kesehatan anak.

d) Kata-kata mengkomunikasikan makna denotasi dan makna konotasi.

Makna denotasi kata-kata dalam iklan akan menciptakan isi. Dalam iklan Sharp, fungsi "polisi" (denotasi) dalam memberi "perlindungan" telah diartikan dan digunakan secara luas untuk mewakili makna perlindungan yang akan diberikan oleh Sharp Plasmacluster Air Purifier. Sedangkan makna konotasi iklan tersebut berhubungan dengan makna subjektif yang diberikan oleh pengiklan terhadap penggunaan polisi penjaga keluarga dari serangan musuh yaitu bakteri, jamur dan virus berbahaya. Pilihan gambar robot yang sedang menembak mati kuman, diksi "musuh", "lawan" dan "polisi" semakin memperkuat makna konotatif dibutuhkannya pendekatan kekerasan dalam mengatasi musuh keluarga, yaitu, sekali lagi, bakteri, jamur dan virus berbahaya.

Sementara itu, iklan sabun Dettol menampilkan makna denotasi kekhawatiran para ibu dan aktifitas bermain anak-anak yang penuh dengan berbagai kuman penyebab penyakit. Makna konotasi iklan sabun Dettol berhubungan dengan kecenderungan iklan ini untuk “membenarkan' anggapan bahwa ada 100 kuman penyebab penyakit dan para ibu harus yakin bahwa hanya Dettollah yang dapat, lagi-lagi, "membunuh" berbagai kuman penyebab penyakit tersebut.

\section{Mengapa Tetap Penting Untuk Menjadikan Etika Komunikasi Sebagai Standar Dalam Beriklan?}

Item ini dianalisis dengan menggunakan rekomendasi dari Jaksa dan Pritchard tentang pentingnya pertimbangan etika dalam berkomunikasi (Jaksa dan Pritchard, 1994: 12-18). Limarekomendasi dari Jaksa dan Pritchard tersebut yaitu :

Stimulating the moral imagination. Item ini berhubungan dengan pembelajaran tentang apa dampak yang mungkin ditimbulkan dari perilaku kita terhadap orang lain, ketika perilaku kita melibatkan pilihanpilihan sadar tentang cara dan tujuan yang dapat dinilai dengan standar benar- salah. Pilihan kata-kata dalam iklan harus dipahami dalam konteks bahwa kata-kata tersebut bukanlah sekedar instrumen belaka tetapi mengandung nilai moral etis yang harus dijaga.

Fungsi iklan yaitu untuk menciptakan images tertentu tentang produk yang dapat menjual produk tersebut, baik barang maupun jasa. Dalam konteks komunikasi melalui iklan, pesan yang dikirimkan lebih sebagai suatu hasil kreatifitas dan bukan hal yang sifatnya faktual. Sedangkan sifat pesan lebih bersifat persuasif daripada informatif. Meskipun demikian, hal itu bukan berarti bahwa pesan melalui iklan dapat mengabaikan pertimbangan etika. Richard Johannesen (dalam Gordon, Kittross dan Reuss, 1996: 259) 
memberikan arumentasi menarik tentang aplikasi standar etika dalam pesan iklan. Menurutnya, upaya iklan untuk memberikan argumentasi tentang kualitas produk (karena memang tujuan akhir dari iklan yaitu menjual produk) harus mendasarkan diri pada truthfulness dan rationality. Artinya, bukti-bukti dan reasoning yang dipaparkan dalam pesan iklan untuk mendukung klaim atas kualitas produk tersebut haruslah bersifat clear, accurate, relevant and sufficient in quantity. Sedangkan, pendekatan emosional dan atau motivasional yang digunakan dalam pesan iklan haruslah bersifat memiliki hubungan langsung dengan produk yang sedang dipromosikan tersebut. Di titik ini, pesan dalam iklan Sharp dan sabun Dettol menjadi bias, terutama tentang truthfulness dan rationality. Beberapahal yang dapat dipertanyakan, misalnya, sehebat itukah gambaran kemampuan dari Sharp Plasmacluster Air Purifier sebagai "polisinya polusi"? Apa hubungan antara Sharp Plasmacluster Air Purifier dengan fungsi polisi? Dapatkah hasil survey yang dipaparkan dalam iklan sabun Dettol tersebut dipertanggungjawabkan? Benarkah ada angka pasti jumlah kuman yang dapat dibasmi oleh sabun Dettol, mengingat iklan sabun ini mengklaim dapat membunuh 100 jenis kuman penyebab penyakit? Akuratkah usaha persuasif pesan iklan sabun Dettol agar para ibu 100\% yakin terhadap kehebatan sabun Dettol?

Salah satu harapan etis mendasar, yang idealnya menjadi dasar pertimbangan dalam berbagai konteks komunikasi, seperti yang dikemukakan oleh Jaksa dan Pritchard (1994: Bab 3) yaitu keseriusan dan apresiasi terhadap semua nilai penting dalam komunikasi manusiawi. Pilihan kata dan gambar yang ditampilkan dalam kedua iklan tersebut pun tidak luput dari masalah ini. Dari sisi diksi, baik iklan Sharp Plasmacluster Air Purifier maupun iklan sabun Dettol menggunakan katakata yang dikategorikan kekerasan verbal, misalnya "membunuh", "musuh", dan kata "melumpuhkan". Sedangkan dari sisi gambar, iklan Sharp Plasmacluster Air Purifier terang-terangan menggunakan gambar memperlihatkan aksi kekerasan dari sebuah robot yang sedang menembak mati bakteri, jamur dan virus (sayangnya, adegan kekerasan yang dilakukan oleh robot tersebut dilihat oleh ibu dan anak, dalam model iklan tersebut, sambil tersenyum ceria).
Recognizing ethical issues. Item ini berhubungan dengan kemampuan mengenali dimensi moral dalam setiap situasi. Dibutuhkan pengenalan kritis atas situasi yang dihadapi serta melibatkan penilaian tentang tanggapan seketika, mengidentifikasi asumsi-asumsi yang tidak stabil serta mempertanyakan apakah "tanggapan" secara berdiri sendiri dapat dijadikan sebagai dasar penilaian moral, dan sebagainya. Dalam konteks komunikasi melalui pesan iklan, potensi masalah etika juga berada dalam wilayah kerja proses pembuatan iklan. Iklan yang menarik haruslah kreatif. Persoalannya mulai muncul ketika tuntutan untuk kreatif dihadapkan dengan idealisme untuk menggunakan reasoning yang rasional dalam menggambarkan kehebatan produk. Berkaitan dengan hal tersebut, Richard Johannesen (dalam Gordon, Kittross dan Reuss, 1996: 260) mengingatkan tentang the basic persuasive nature of advertising. Artinya, ada perbedaan antara rasionalitas dalam menjelaskan kualitas produk, di satu sisi, dengan kreatifitas untuk menggambarkan kualitas tersebut, di sisi yang lain, dengan tujuan untuk mendapatkan perhatian audiens. Di sinilah potensi masalah etika mulai muncul atau apa yang oleh Gordon di sebut sebagai lack a clear dividing line (Gordon, Kittross dan Reuss, 1996: 260). Idealnya, kreatifitas tidak mengalahkan dan atau mengabaikan rasionalitas. Bagaimana dengan iklan Sharp dan iklan sabun Dettol yang menjadi objek penelitian ini? Nampaknya, kedua iklan tersebut juga masih terjebak dalam jurang antara rasionalitas dan kreatifitas dalam menonjolkan kualitas produk. Rasionalitas reasoning tentang perlindungan keluarga dengan menggunakan Sharp Plasmacluster Air Purifier tidak dapat terpenuhi hanya dengan klaim bahwa Sharp Plasmacluster Air Purifier berfungsi sebagai "polisinya polusi". Sedangkan kreatifitas dalam menggambarkan robot yang sedang menembak mati kuman, bakteri dan virus pun akhirnya bersinggungan dengan masalah kekerasan verbal dalam gambar.

Eliciting a sense of obligation. Dengan item ini, Jaksa dan Pritchard ingin mengingatkan tentang value bahwa penerapan etika dalam praktek jauh lebih penting daripada sekedar penyederhanaannya sebagai persoalan intelektual semata. Item ini terkait dengan apa yang oleh Jaksa dan Pritchard (1994: 15) 
diidentifikasi sebagai situasi yang membutuhkan refleksi moral dalam pengambilan keputusan. Penjelasan tentang item ini sekaligus juga menguraikan gagasan tentangDeveloping analytical skillsdari kedua iklan tersebut.

Developing analytical skillsberkaitan dengan kemampuan individu untuk berpikir kritis tentang konsep-konsep dasar pertimbangan nilai etika. Misalnya, keadilan, fungsi dan manfaat, tanggungjawab, hak, tugas, penghargaan terhadap diri sendiri dan orang lain, martabat, otonomi, $d s b$, sehingga kemudian konsep-konsep dasar pertimbangan nilai etika tersebut dapat diterapkan secara konsisten dan koheren.Bagaimana konsepEliciting a sense of obligationdan developing analytical skillsini dipahami dalam konteks komunikasi melalui iklan? Edmund Lambeth (dalamGordon, Kittross dan Reuss, 1996: 263) menyebutkan bahwa salah satu prinsip dasar yang harus diaplikasikan dalam komunikasi melalui iklan yaitu prinsip humaneness. Menurut Lambeth, iklan harus menghindari eksploitasi terhadap individu dan atau kelompok, terutama gagasan agar iklan do not direct, intentional harm to others.

Keputusan untuk mengikuti ataupun mengabaikanrekomendasi Lambeth tersebut sepenuhnya berada di tangan pembuat iklan. Apakah prinsip humanenesstersebut akan dijadikan sebagai dasar dalam berkreatifitas ataukah hanya akan sekedar menjadi lip-service tentang etika iklan. Iklan Sharp Plasmacluster Air Purifier, misalnya, mengeksploitasi fungsi orang tua dalam memberikan perlindungan terhadap anak-anak (keluarga). Keluarga hanya bisa terlindungi jika menggunakan teknologi tinggi yang dimiliki oleh produk tersebut. Sedangkan, dalam iklan sabun Dettol, kekhawatiran para ibu tentang jenis penyakit yang biasanya menyerang nak-anak dieksploitasi dengan menyuguhkan data survey yang menggunakan data-data fantastik tanpa jaminan legalitas dan cenderung memunculkan rasa takut. Misalnya, penggunaan kata "ribuan ibu" (yang khawatir), "Dettol baru-baru ini melakukan survey" (tidak jelas kapan, dimana dan bagaimana metode survey yang digunakan), "53 penyakit yang membuat mereka khawatir" (tanpa ada penjelasan apapun tentang 53 jens penyakit tersebut), " $25 \%$ dari total kasus diare yang menyebabkan kematian anak berumur 1 - 4 tahun" (tidak jelas sumber data), serta kalimat "Dettol 100\% yakin membunuh kuman" (tidak ada ruang bagi kegagalan produk sabun Dettol dalam membunuh kuman)

Tolerating disagreement. Masalah moral sangat mungkin menimbulkan pro-kontrabahkan menimbulkan keraguan dan ketidakpastian. Walaupun sulit mendapatkan kepastian moral, namun alasan yang melatarbelakangi suatu pilihan moral dapat dibuat secara tepat, jika adatoleransi terhadap pilihan yang berbeda yang memiliki alasan moral yang dapat dipertanggungjawabkan.Memahami item ini dalam konteks komunikasi melalui iklan, pada akhirnya akan berhubungan dengan kompleksitas pemaknaan antara "tujuan dan cara" (endsmeans problem) (Merrill, dalamGordon, Kittross dan Reuss, 1996: 272). Tujuan iklan yaitu menciptakan images dan menjual produk. Pertanyaannya sekarang yaitu apakah untuk mencapai tujuan tersebut harus dengan cara mengatakan yang sebenarnya tentang produk (kebenaran)? Makna deontologist akan menyodorkan gagasan bahwa mengatakan kebenaran adalah "harga mati" karena kebenaran itu sendiri adalah prinsip dasar dalam etika. Tetapi, di sisi lain, dari makna teleological, mempertimbangkan untuk meluputkan iklan dari keharusan mengatakan kebenaran karena iklan itu sendiri needs to create good images and make sales(ini berhubungan dengan kreatifitas).

Makna dalam cara berpikir teleological yang sangat pragmatis tentu saja tidak bisa disandingkan dengan makna dalam cara berpikir deontologist yang sangat ethical. Disinilah dibutuhkan reasoning tentang sampai dimana batasan kreatifitas tersebut dapat diterima. Para pembuat iklan pasti akan memiliki alasan yang berbeda-beda dan rasional (setidaknya menurut pendapat mereka) tentang diksi dan pilihan gambar dalam setiap iklan yang mereka hasilkan. Merrill pun merekomendasikan gagasan tentang pilihan untuk menjadi pragmatis atau ethical (dalamGordon, Kittross dan Reuss, 1996: 272). Menurutnya, keputusan atas "tujuan dan cara", dalam mengemas pesan iklan, dapat dipertanggungjawabkan sepanjang keputusan tersebut tidak menghasilkan "mis-representation, to providing false images, to exaggerated expectations, to 
unwarranted expenditure of money, and often to getting something that does not live up to promises".

Bagaimana memahami penjelasan tersebut dalam konteks Iklan Sharp Plasmacluster Air Purifier dan iklan sabun Dettol? Mis-representasi tentang "keluarga yang membutuhkan polisinya polusi di dalam rumahnya dan bahwa keluarga modern yang bahagia diukur dengan kepemilikan Sharp Plasmacluster Air Purifier, menjadi bagian yang tidak terelakkan dari iklan tersebut. Sedangkan dalam iklan sabun Dettol, false images terjadi ketika iklan tersebut berusaha mempersuasif dengan menyodorkan data survey yang tidak dapat diuji kebenarannya, yang akhirnya menyebabkan slogan "Dettol $100 \%$ yakin membunuh kuman" pun menjadi slogan yang melambungkan harapan calon konsumen tanpa kepastian tentang kebenaran slogan tersebut.

\section{PENUTUP}

Penelusuran makna denotasi dari kedua iklan tersebut menunjukkan adanya kecenderungan kekerasan verbal melalui pilihan kata dalam penonjolan fungsi produk. Pengiklan memilih menggunakan kata - kata seperti "polisi', mengancam" dan "membunuh" untuk menunjukkan fungsi dan keunggulan produk yang mereka tawarkan. Ironisnya, dalam makna konotasi, pilihan kata - kata tersebut dipakai untuk menunjukkan aktifitas keseharian orang tua (dalam hal ini "ibu") dan anak. Pada tataran selanjutnya, dalam kedua iklan tersebut akhirnya memiliki potensi masalah etika yang berhubungan dengan diksi dan pilihan gambar yang ditampilkan. Masalah etika yang ditemukan yaitu berkaitan dengan kemampuan kata-kata untuk menciptakan dunia, kata-kata yang memiliki kemampuan untuk mempengaruhi pikiran dan tindakan, serta kemampuan kata-kata untuk mempengaruhi dan merefleksikan budaya. Apa yang oleh Gordon, Kittross dan Reuss sebut sebagai lack a clear dividing line nampaknya menjadi benang merah dari potensi masalah etika dalam penelitian ini. Penggambaran kreatif iklan yang masih terjebak dalam interpretasi atas truthfulness dan rationality, misalnya, akhirnya membuat kedua iklan tersebut membutuhkan proses penyaringan konseptual yang lebih selektif dari masyarakat yang menerima (membaca) iklan tersebut. Dalam situasi seperti itu, ada beberapa alasan mendasar mengapa tetap penting untuk menjadikan etika komunikasi sebagai standar dalam beriklan. Pertama, Stimulating the moral imagination. Temuan penelitian ini menunjukkan bahwa pesan dalam iklan Sharp dan sabun Dettol menjadi bias, terutama tentang truthfulness dan rationality. Kedua, Recognizing ethical issues. Di item ini, kedua iklan tersebut terjebak dalam jurang antara rasionalitas dan kreatifitas dalam menonjolkan kualitas produk. Ketiga, Eliciting a sense of obligation dan developing analytical skills. Penerapan kedua item ini masih mengabaikan prinsip humaneness, sehingga prinsip tersebut nampaknya masih sebatas lip-service tentang etika iklan. Keempat, Tolerating disagreement. Hasil penelitian ini menunjukkan bahwa masih terjadi mis-representasi dan false images dari kedua iklan tersebut.

Beberapa hal yang dapat direkomendasikan melalui penelitian ini, yaitu pertama, rekomendasi akademis. Masih dibutuhkan penelitian lanjutan tentang penerapan prinsip dasar etika dalam berbagai kategori iklan lainnya, agar dapat dihasilkan peta yang komprehensif tentang masalah etika dalam komunikasi melalui iklan. Kedua, rekomendasi praksis. Bagi para pembuat iklan. Tujuan tidak menghalalkan cara. Pengutamaan prinsip-prinsip dasar etika tetap relevan untuk diaplikasikan dalam konteks komunikasi melalui iklan. Meskipun demikian, tetap harus diakui bahwa keputusan akhir tentang gagasan ini tetap berada di tangan para pembuat iklan. Ketiga, rekomendasi sosial. Iklan sudah menjadi bagian yang tidak terpisahkan dari keseharian masyarakat. Iklan hadir dalam berbagai bentuk sesuai dengan media yang dipilih oleh para pengiklan. Tujuan utama iklan untuk mendekatkan produk kepada masyarakat, yang didalamnya tentu saja akan digunakan berbagai cara agar masyarakat dapat menerima dan menggunakan produk yang ditawarkan tersebut. Dalam situasi seperti itulah dibutuhkan kepekaan dari masyarakat untuk tetap bijak membedakan apa yang sesungguhnya menjadi kebutuhan dan mana yang hanya sekedar keinginan saja. Kepekaan masyarakat juga dibutuhkan sebagai salah satu fungsi penjaga gerbang, sehingga pada akhirnya masyarakat mampu mengabaikan iklan yang hanya mengutamakan "menjual produk" tanpa peduli dengan hak konsumen untuk mendapatkan iklan yang 
juga mencerdaskan.

\section{DAFTAR RUJUKAN}

Baryadi, I. Praptomo. (2007). Teori Ikon Bahasa: Salah Satu Pintu Masuk ke dunia semiotika. Yogyakarta: Penerbit Universita Sanata Dharma

Beebe, Steven A, Susan J. Beebe dan Mark V. Redmon. (2005). Interpersonal Communication. Relating to Others. Boston: Pearson Education, Inc

Bertens, K. (2007). Etika. Jakarta: Gramedia Pustaka Utama

Cutlip, Scott M, Allen H. Center dan Glen M. Broom. (2009). Effective Public Relations. Edisi 9 (Terjemahan). Jakarta: Kencana Prenada Media Group

Denzin, Norman K dan Yvonna S. Lincoln. (2009). Handbook of Qualitative Research. Cetakan 1. Edisi Terjemahan. Yogyakarta: Pustaka Pelajar

Gordon, A. David, John M. Kittross, dan Carol Reuss. (1996). Controversies In Media Ethics. New York: Longman

Haryatmoko. (2007). Etika Komunikasi. Manipulasi Media, Kekerasan dan Pornografi. Yogyakarta: Penerbit Kanisius

Hendy, Y. (2009). Belajar Membuat Iklan Sukses dengan Contoh Sketsa Ide dan Iklan. Yogyakarta: Graha Ilmu

Jaksa, James A dan Michael S. Pritchard. (1994). Communication Ethic. Methods of Analysis. Second Edition. California: A Division of Wadsworth, Inc.

Mickey, Thomas, J. (2003). Deconstructing Public Relations. Public Relations Criticism. New Jersey: Lawrence Erlbaum Ass, Pub.

Sobur, Alex. (2002). Analisis Teks Media. Suatu Pengantar untuk Analisis Wacana, Analisis Semiotik, dan Analisis Framing. Bandung: Remaja Rosdakarya

Sobur, Alex. (2003). Semiotika Komunikasi. Bandung: Remaja Rosdakarya.

\section{Dokumen Eksternal}

Iklan AC Sharp (Majalah "ayahbunda" nomor 26 Edisi 24 Desember 2012 - 6 Januari 2013, halaman 3)

Iklan sabun cair Dettol (Majalah "ayahbunda" nomor 20 Edisi 06 - 19 Oktober 2014, halaman 45)

\section{Internet}

KKBI Daring:https://kbbi.kemdikbud.go.id/

https://www.sharp-indonesia.com,

http://www.ayahbunda.co.id

www.dettol.co.id 